receives the honour which has always been her due. An interesting note on spontaneous combustion, of which 150 cases have been recorded, points a finger at gin and reminds us that Marryat was not romancing when he let poor Jacob Faithful see his mother end this way. Besprinkled with illustrations and with light and often entertaining verse, this Bulletin will, we hope, live on to lighten the strain of the busy practitioner's life.

\section{Coconut Milk Growth Factor}

THat the watery endosperm of the coconut contains the growth-promoting 'coconut-milk factor' at all stages of development has been shown by F. C. Steward and S. M. Caplin (Ann. Bot., N.S., 16, 64 ; 1952). Some activity is also shown by parts of the immature embryo but not by the solid endosperm. Growth-promoting substances of analogous activity have been detected in the immature milky endosperm of maize, in the gelatinous material in immature walnut fruits, and in the young gametophyte of Ginkgo biloba. The tissues from which these substances have been obtained appear to grow at the expense of, or to be nourished by, the nucellar tissue. In Cocos (coconut), Zea (maize) and Juglans (walnut) it is the immature embryo that eventually benefits from the growth factor. The conditions that are conducive to the accumulation of the substance seem to involve, or to be associated with, a delay in the growth of the embryo but a precocious formation of the endosperm.

\section{Optics and Microwaves: Conference in Milan}

A CONFEREnce on "Optics and Microwaves" was held in Milan during June 9-11, 1952, under the auspices of Unesco, the International Union of Pure and Applied Physics, the Consiglio Nazionale delle Ricerche, the Commissione Nazionale Italiana per l'Ottica, and the Società Italiana di Fisica. A special supplement of Nuovo Cimento containing the proceedings of this conference has now been published (Supp. 3 to Vol. 9, Ser. 9; 1952. 2,500 lire). It includes the twenty-seven original communications presented and discussed at the conference and a summary of the work of the conference, written by Prof. R. Malvano, of Turin ; a very full account of the discussion is also given. Two of the main subjects treated are the spectroscopy and polarimetry of radiations from infra-red to microwaves; the phenomena of diffraction and propagation (including all the problems relating to the resolving power and to the antenna radiation pattern). Among the most important contributions reported are the following: a microwave spectroscope for the $1 \cdot 25-\mathrm{cm}$. wave region $(J, \mathrm{C}$. van den Bosch and F. Bruin); measurement of the velocity of electromagnetic waves and the refractive index of air at microwave frequencies (L. Essen and K. D. Froome); experimental demonstration of microwaves and their optical analogues (G. F. Hull, jun.) ; applications de la géométrie différentielle à l'optique des microondes (K. S. Kunz); spectroscopy near the boundary between the microwave and infrared regions (A. H. Nethercot, J. A. Klein, J. H. N. Loubser and C. H. Townes) ; methods of light opties for the calculation of the diffraction phenomena within the range of centimetre waves (H. Severin); une optique correctrice pour les projecteurs d'onde U.H.F. (J. C. Simon); super-gain antennæ and optical resolving power (G. Toraldo di Francia); and theory and applications of surface waves (F. J. Zucker).

\section{Seminar on Polymer Science}

As a continuation of an earlier seminar (see Nature, 171,$65 ; 1953$ ) four lectures were given in the Chemistry Department in University College, London, on June 29. Prof. H. F. Mark described the preparation and properties of co-polymers containing long stretches of monomer units in one single macromolecule. If one stretch of the monomer unit is water-soluble and another stretch of different monomer units is oil-soluble, solutions of the resulting co-polymer have interesting colloid chemical properties. Samples of such co-polymers were demonstrated. Further work discussed by Mark dealt with the structure of polythenes, with the determination of the molecular weight distribution of polymers by a novel method developed by Debye, and with the influence of stress on swelling; the latter effect being demonstrated by a lecture experiment. Dr. C. W. Bunn discussed melting points of chain polymers, and Dr. I. R. G. Treloar outlined the type of conclusions which can be derived from a study of photoelastic effects of polymers. He showed that in certain cases the stress optical coefficient is a specific molecular quantity which can be used to estimate the length of a statistical chain element. This lecture included demonstrations of photo-elastic effects in crystalline and amorphous polymers. Dr. K. Bailey dealt with certain properties of filamentous muscle proteins. He showed that the rotational relaxation times of these polyampholytes can be estimated by Weber's method (involving the measurement of the polarization of fluorescent light), and he reported results showing in which way these relaxation times are affected by chemical conditions. Each lecture was followed by a discussion which was facilitated by circulating short abstracts in advance.

\section{United States National Science Foundation: Fellow- ship Awards and Research Grants}

For the academic year 1953-54 the United States National Science Foundation has awarded 556 graduate fellowships in the natural sciences out of 3,298 applications from all parts of the continental United States, Hawaii and Puerto Rico ; in addition, 1,274 applicants were given an 'honorable mention'. 515 awards were made to graduates studying for doctorates (180 first year, 166 intermediate and 169 final year) and 41 to post-doctorate students. The fellowships are awarded on the basis of academic record and recommendations and, in addition, the pre-doctorate students were required to take examinations ; in cases of substantially equal merit, the choice was made so as to result in a wide geographical distribution. 'The list includes 175 awards to those already holding Foundation fellowships, though for the new awards they had to compete afresh. The distribution by subjects is as follows: chemistry, 129 ; physics, 115 ; engineering, 63 ; mathematics, 56 ; zoology, 38 ; biochemistry, 35 ; geosciences, 26 ; botany, 19 ; microbiology, 18; biophysics, 14 ; medical sciences, 13 ; genetics, 11; psychology and anthropology, 10 ; and agriculture, 9. Fellows may study at any non-profit institution of higher education in the United States or, subject to approval, abroad. 'The stipends are 1,400-1,800 dollars for pre-doctorate students and 3,400 dollars for those holding doctorates. The Foundation has also announced the award of sixty grants, totalling 469,550 dollars, to institutions in the United States for the support of studies and conferences on science and scientific education. This is the third group of awards for the fiscal year 